PLANTS PEOPLE

POSSIBILITIES

Sassafras in China. (Sassafras Tzumu, Hemsl.)

Author(s): W. B. Hemsley

Source: Bulletin of Miscellaneous Information (Royal Botanic Gardens, Kew), Vol. 1907, No. 2 (1907), pp. 55-56

Published by: Springer on behalf of Royal Botanic Gardens, Kew

Stable URL: http://www.jstor.org/stable/4111625

Accessed: 21-06-2016 09:36 UTC

Your use of the JSTOR archive indicates your acceptance of the Terms \& Conditions of Use, available at

http://about.jstor.org/terms

JSTOR is a not-for-profit service that helps scholars, researchers, and students discover, use, and build upon a wide range of content in a trusted digital archive. We use information technology and tools to increase productivity and facilitate new forms of scholarship. For more information about JSTOR, please contact support@jstor.org. access to Bulletin of Miscellaneous Information (Royal Botanic Gardens, Kew) 
BRITISH FAST A FRICA. Nyasaland : Blantyre, Scott ; Mount Mlanji, Whyte; Mlanji Plateau, McClounie; Uvera, Miss $E$. Kenyon; Nyika Plateau, McClounie, 30.

In the Flora of Tropical Africa, v. 342, these plants were included under $O$. affine, Hochst., which differs in having broader leaves and non-denticulate corolla-lobes.

900. Dasystachys nervata, C.H. Wright [Liliaceae-Asphodeleae]; D. Grantii, Benth., affinis, quae bracteis quam flores multo longioribus foliisque flaccidis recedit.

Rhizoma ignotum. Folia per anthesin $15 \mathrm{~cm}$. longa, $1.5 \mathrm{~cm}$. lata, oblonga, acuminata, rigida, apice cucullata, utrinque glaberrima, nervis primariis circa 17 prominentibus. Scapus $22 \mathrm{~cm}$. longus, cylindricus; parte superiore minute puberulus; racemus $10 \mathrm{~cm}$. longus, rhachide pedicellisque glabri; pedicelli $2 \mathrm{~mm}$. longi. Perianthii segmenta oblonga, valde concava, obtusa, $3.5 \mathrm{~mm}$. longa, $1.5 \mathrm{~mm}$. lata, alba, extus ad apicem luteo-puberula, uninervia. Stamina perianthii segmentis paullo breviora; filamenta e basi lanceolata complanata subulata ; antherae $1.5 \mathrm{~mm}$. longae, $1 \mathrm{~mm}$. latae, obtusae. Ovarium trilobum; lobis globosis; stylus ovario aequilongus, columnaris ; stigma punctiforme; ovula in quoque loculo 4-6. Capsula $4 \mathrm{~mm}$. diam.

RHODESIA. Between Broken Hill zinc mine and Bwana M'cuba copper mine, C. E. F. Allen, 338 .

\section{XI.-SASSAFRAS IN CHINA.}

(Sassafras Tzumu, Hemsl.)

W. B. HEMSLEY.

A few days before Mr. Wilson left on his third journey to China, he brought me some specimens of a laurel, collected by himself in the l'atung district of Hupeh, which he had identified with the North American Sassafras officinale, Nees, and also with my Lindera Tzumu (Journ. Linn. Soc., vol. xxvi. p. 392) and Litsea laxiflora (loc. cit. p. 383, t. 8). He was quite right as to the two last, which were described from imperfect materials; the former from a specimen bearing young fruit, and the latter from a specimen bearing flowers of one sex only and no leaves; both instances of imprudence in founding species on imperfect specimens. He was also right, I think, as to the Chinese tree being a species of Sassafras; but, although there is a striking similarity between the dried specimens from China and those of S. officinale from North America, an examination of the flowers has revealed differences that are almost of generic importance, as the genera of Lauraceae are limited. Both species have heteromorphic, deciduous leaves with the same kind and range of variation, and the inflorescences of both sexes, which appear before the leaves, present no obvious differences. The flowers of the North American species are, however, somewhat larger, and the floral diagram is quite different. I have not examined a large number of flowers, but 
those examined agree with the descriptions and the excellent figures in Sargent's "Silva of North America," vol. vii. t. 304. Only a small number of flowers of the Chinese species were examined, but they were so far uniform in structure. The following is a comparison of the flowers of the two species :-

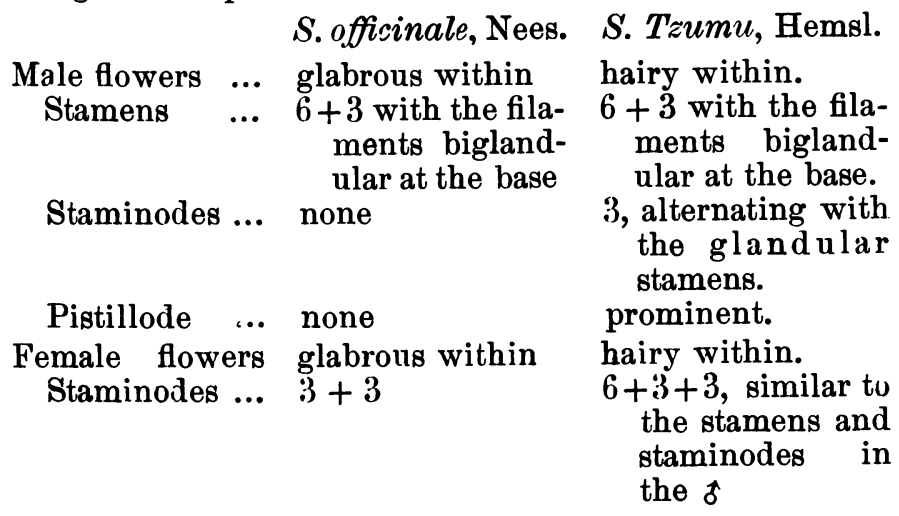

As it is intended to publish a figure and full description of S. T'umu in Hooker's Icones Plantarum, the foregoing differential characters will be sufficient here.

As Sargent remarks, Sassafras officinale or Sassa fras Sassafras, as he has called it, was probably one of the first North American trees to be.introduced into Europe. Gerarde describes it in his "Herbal "(1597), and in Johnson's edition of the same work (1633), he states that his figure was made from a small tree growing in the garden of Mr. Wilmote at Bow, some few years previously. In 1838 Loudon (Arboretum Britannicum, vol. iii. p. 1303) recorded specimen trees at Kew and Syon House sixty feet high, and the latter as having a trunk three feet in diameter.

Sassafras Tzumu, Hemsl., is a valuable timber tree which, on the authority of Dr. A. Henry, sometimes attains very large dimensions. It is the tzu-mu or huang-chin of Central China, and appears to be abundant in the Province of Hupeh. Kew also possesses specimens from Ningpo, Chekiang (Faber), and from Kiukiang, Kiangsi (Maries).

\section{XII.-DECADES KEWENSES}

\section{Plantarum Novarum in Herbario Horti Regit Conservatarum.}

\section{DECAS XLIII.}

421. Aconitum Gammiei, Stapf [Ranunculaceae]; affinis $A$. leucantho, Stapf, differt glabritie, foliis multo magis dissectis divisionibus linearibus brevius petiolatis, galea magis depressa et magis hiante, nectario haud calcarato, sed in dorso basin cucullae versus gibbosa. 